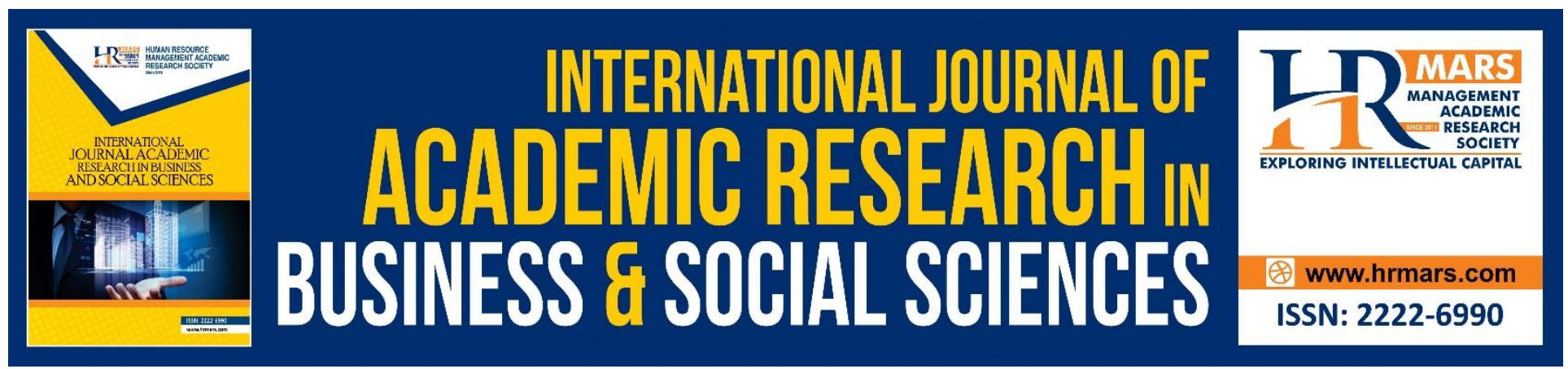

\title{
Fair Value Accounting: A Conceptual Approach
}

\author{
Ohidoa Toluwa, Otakefe Joseph Power
}

To Link this Article: http://dx.doi.org/10.6007/IJARBSS/v9-i6/5982

DOI: $10.6007 /$ IJARBSS/v9-i6/5982

Received: 11 April 2019, Revised: 24 May 2019, Accepted: 03 June 2019

Published Online: 27 June 2019

In-Text Citation: (Toluwa \& Power, 2019)

To Cite this Article: Toluwa, O., \& Power, O. J. (2019). Fair Value Accounting: A Conceptual Approach. International Journal of Academic Research in Business and Social Sciences, 9(6), 683-696.

Copyright: (C) 2019 The Author(s)

Published by Human Resource Management Academic Research Society (www.hrmars.com)

This article is published under the Creative Commons Attribution (CC BY 4.0) license. Anyone may reproduce, distribute, translate and create derivative works of this article (for both commercial and non-commercial purposes), subject to full attribution to the original publication and authors. The full terms of this license may be seen at: http://creativecommons.org/licences/by/4.0/legalcode

Vol. 9, No. 6, 2019, Pg. 683 - 696

http://hrmars.com/index.php/pages/detail/IJARBSS

JOURNAL HOMEPAGE

Full Terms \& Conditions of access and use can be found at http://hrmars.com/index.php/pages/detail/publication-ethics 


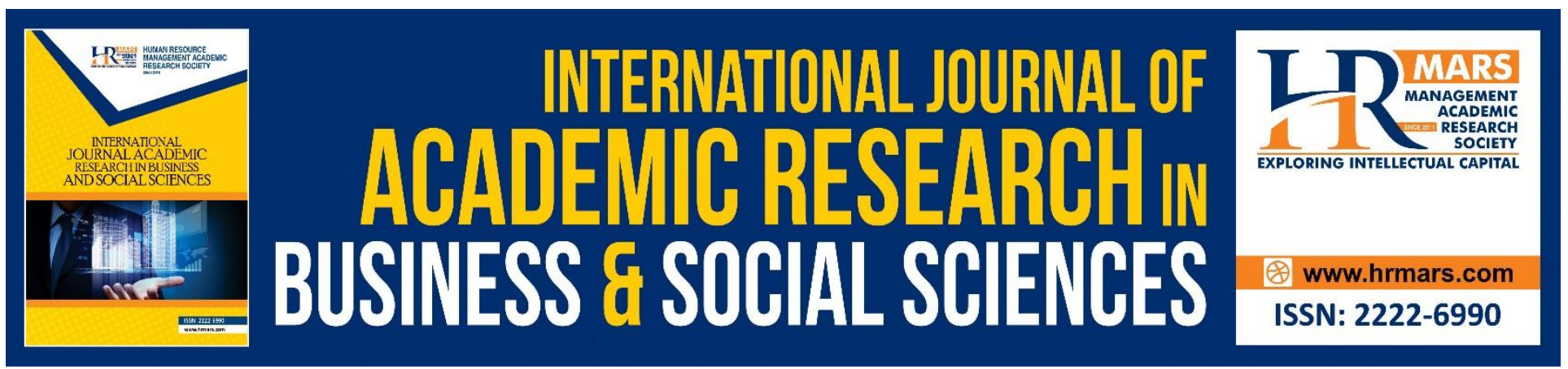

\title{
Fair Value Accounting: A Conceptual Approach
}

\author{
Ohidoa, Toluwa (BSc, MBA, M.Sc), Otakefe Joseph Power (B.Sc, \\ M.B.A, Ph.D)
}

Department of Accounting, Faculty of Management Sciences, University of Benin, Benin City. Email: evetolambassador@gmail.com

\begin{abstract}
This study critically looked at the controversial issues surrounding fair value accounting approach. The study extensively reviews relevant literature on fair value accounting relevance and reliability to financial reporting. To achieve the objective of the study, the study employed a library research methodology. Findings in this study revealed contentions issues such as: Fair value measurement and verification; financial instrument measurement; cyclical effect of fair value accounting; Also, the study found that, the reliability and relevance of fair value accounting approach is tied to; market liquidity, presence of active market, and uninterrupted market environment; and finally, fair value accounting influences entities' earnings which invariably affect earnings quality. Based on our conceptual findings, we therefore recommend that: first, there should be an empirical study to ascertain the effect of fair value accounting on firms' earnings in an emerging country like Nigeria, this will help to know if results will negate or corroborate with prior findings; second, there is need to strive and improve the emerging markets business environments in order to create an active markets for optimal realization of objective of fair value valuation method; finally; standard setters should set rules and equivocal guidelines to limit uncertainties and ambiguities in handling the application of level three of fair value hierarchy.
\end{abstract}

Keywords: Fair Value, Financial Instruments, Earnings, Relevance and Reliability

\section{Introduction}

The principal medium through which corporate business entities convey their financial position and worth to various stakeholders is by published financial statements. And the relevance and reliability of entity's financial statements depends on the usefulness of information conveyed to the end users. Therefore, the choice of the method of estimate employed in the preparation of the financial statements, has become a significant challenge in accounting discipline; as the scope of business entities' operations are becoming global. More also, entities' process and corporate methods are increasingly growing across borders, and corporate performances of entities are receiving its due 
recognition. This is accompanied by the flooding of financial markets by complex trade able financial products (physical products and financial instruments).

Barth (2007), the primary activity in the overall process of financial reporting is the value measurement. Selecting a suitable evaluation base, such as the fair value at entry, historical cost, and fair value at exit (net realizable value), is open to the managerial discretion of the entity. Financial reporting under the fair value based accounting system states assets and liabilities at their respective current values. International Accounting Standard Board (2012); Financial Accounting Standard Board (2009); and International Financial Reporting Standard 13, defined fair value as the price that would be received to sell an asset or paid to transfer a liability in an armlet transaction between market buyers and sellers at the measurement date.

In an attempt to address the challenges of financial statements reporting in the present global business environment, standard setters (International Accounting Standard Board and Financial Accounting Standard Board) have significantly re-modified financial statements reporting systems, with fair value accounting(PricewaterhouseCoopers, 2015). This development had resulted to a gradual shift from the historical accounting approach towards the fair value accounting approach. Eckstein (2004) and ljeoma (2014), the wave of financial reporting is moving towards 'relevance' of financial reporting to stakeholders. These aforementioned Parties have motivated this transition back from the traditional approach to the fair value accounting approach, thereby, signaling a significant shift in the underlying conceptual basis of financial reporting. Therefore, the appropriateness of matching income with the market place, using market based measure, had become a dominant discussion in financial reporting palace that has introduced the era of fair value accounting measure (Jatinder, 2017).

Chambers (2008), fair value accounting is the method of accounting that estimates certain liabilities and asset of an entity at its current market value, which seeks to report the current value of future cash flows related to an entity's assets or liabilities. Fair value accounting is the price that would be received to dispose an asset or transfer a liability in an orderly transaction between market participants at the measurement dates. In fair value accounting, entities report losses when the fair values of their assets decrease or liabilities increase. The losses reduce entities' reported equity and probably also reduce entities' reported net income. The concept of fair value estimation has been a controversial issue in accounting research, the cloudiness associated with fair value measurement remained unresolved in prior studies (Magnan, 2009; Alves, Botinha, Silva, \& Lemes, 2015; Sodan, 2015).

The financial crisis of 2007-2009 sparked the interest of researchers to the consequences of fair value accounting, and since then, its application has received more critics than positive comments (Laux \& Leuz, 2010). In literature, the application of fair value accounting has given rise to different interpretations and till date, no shared agreement on the effects of fair value accounting measure on 2007-2009 financial crises (Coppers, 2015). The argument over the role played by fair value accounting during the crisis is still an impending issue for academic researchers. The severity of the global financial crisis and the economic financial meltdown, made many critics to blamed fair value accounting for the occurrence (Sodan, 2015). One of the reasons for the critics of fair value accounting measure within the circumference of the financial crisis, was the suspected pro-cyclicality effects that, fair value accounting could have on financial statements. Although the role of FVA in 
determining the financial crisis has not been studied widely and also, till date, it is still inconclusive and uncertain of the presumed pro-cyclical effect of FVA could have on reliability of financial reporting.

However, despite the alleged demerits of FVA approach, there are some important arguments in favour of the FVA. The use of market prices for preparing accounting reports is useful to investors and authorities, as they deliver more relevant information on a firm's current performance Ebling (2001; Poon 2004). FVA still obtains extensive general support from the accounting profession, standard setters and financial institutions (Catty, 2009). Amidst the conflicting arguments, gave credence to this study to conceptually look at some contending issues in fair value accounting measurement approach. Therefore, the main thrust of this study is to conceptually discuss some unresolved issues in FVA literature, and then respond to the following three questions as drivers of this study. First, what are the specific factors that undermine the relevance and reliability of fair value accounting? Second, does FVA enhance earnings quality? How promising is FVA? Following this introduction, the remaining part of this study is structured as follow; the concept of FVA, FVA measurement and verification issues, financial instrument measurement, pro-cyclical effect of FVA, FVA versus earnings, conclusion and recommendations.

\section{Fair Value Accounting}

Historically, the 1980's saving and Loan crises in United States of America, later resurrected fair value accounting from its extinction and made it more prominence. During this era, financial institutions that held many financial instruments at historical cost values, witnessed financial strains. Most financial institutions became aware that, the value of their financial reporting position could be improved by selling off those assets held on historical book value at a fair value greater than the book value (historical cost value). On the other hand, assets with market values less than book values were retained by financial institutions; the reason for this action was because selling this class of assets could only lead to a decline in the reported book equity of entities. Arising from this situation, many financial institutions were left with asset portfolios characterized with underperforming and weak assets. And eventually, many of the financial institutions eventually went insolvent (Magnan, 2009). Since then, a long-term project to incorporate fair value accounting measurement of financial assets and liabilities of entities by the Financial Accounting Standard Board (FASB) began. For instance, International Accounting Standard 16 (Property, Plant, and Equipment), IAS 38 (Intangibles), IAS 40 (Investment Property) allow reporting entities to opt either for the revaluation or the cost model, and most financial instruments moderated in IAS 39 and 32 however, have to be recognized at fair value (Casualty, 2000; Watanabe, 2007).

\section{Controversial Issues in Fair Value Accounting Estimation Reliability, Relevance and Verification}

Fair value accounting basically revolves around the issues of relevance and reliability. The concept of reliability, is one of the qualitative characteristics of financial statement which is defined as the quality of information that assures that financial statement information is reasonably devoid of errors and biases, and it faithfully represent what it purports to represent (Ilaboya, 2008). In literature, fair value as a measure of exit value is explicitly explained without controversy only in under normal 
market situation and in an organized markets setting. That is, a market condition where the problem of illiquidity does not exist, that is, a smooth running market situation (Allen, 2008). The inference from this statement is that, in a market situation like that of developing countries that are characterized with illiquidity and lack of financial transparency, the measurement of fair value of assets and financial instruments will inevitably be based on unscientific prediction of future cash flow, and the choice of correct discount rates, will equally involve prediction base on managerial assumptions and measurement error. In this case, the possibility of manipulation of accounting numbers is high, and this reduces reliability and relevance of financial reporting (Leggett, 2015).

Therefore, the reliability of fair value measure of assets and liability is based on the level of markets liquidity, inactive markets and financial transparency in a country; and for all assets and liabilities, fair value accounting would only be reliable and information useful in the decision-making process if these necessary conditions are fulfilled (Alves et al., 2015). In most markets cases, especially in the developing economies where the level of market illiquidity is still relatively high and scarcity of active markets for financial assets and liabilities, the inputs and methods of fair value measurement is still highly subjective and the valuation could be less reliable (Bies, 2005 \& Chambers, 2008).

On the other hand, the concept of relevance is the capability of financial statement information to make a difference in helping stakeholders to make projections about the results of past, present, and future activities (Poon, 2004). The debate on the ambiguity of the concept of fair value is capable of affecting the comparability of entities' financial statements, that is, it is possible for a particular element to be measured in one entity using fair value and historical cost method, and the same time identifying the fair value of the asset or liability in some circumstances depends on entity's own assumptions, meaning that, several fair values may be found for one element at one time (Alves et al., 2015; Lilien, 2013; Okafor \& Ogiedu, (2012; Prochazka, 2011). Fair Value Measurements and International Financial Reporting Standards (IFRS) 13 on fair value measurement provide a precise description of fair value and detailed disclosure requests for its use within IFRSs. To improve reliability and comparability in fair value measurements, IFRS 13 comprise a fair value hierarchy based on a three tiered valuation process. Precisely, level 1 is used when the present price in a liquid market for just the same instrument can be achieved (that is, mark to market); level 2 is related to the current price in a liquid market for a similar instrument, which must be applied to evaluate the Fair Value of the instrument to be measured (that is, mark to matrix); level 3 needs to apply valuation models that is, mark to model; a situation whereby management uses discretion due to lack of scientific criteria for measurement (Power, 2010). Thus, prior studies have argued against relevance of fair value accounting using level two and level three fair value hierarchies in a country where the active market is not operational (Kaytmaz, 2014; Liao, 2014; Kaya, 2013; Badertscher, 2012; Ronen, 2012; Landsman, 2007; Barth \& Landsman, 1995). Still on the argument against the relevance of fair value measurement, Ball (2006) based his assertion on the premise that, fair value estimation method does not reflects the true market price of assets and liabilities of entities, as it is easily prone to manipulation (Jordan, 2013). The argument is that, the scarcity of active market in practice means that fair value evaluation of asset or liability of entities will inevitably be measure based on level two or level three of fair value hierarchies, as these two levels are porous and highly subjective to evaluation of managerial discretions (Leggett, 2015). 
Furthermore, the estimation based on fair value technique is more complex if level 3 is used to determine the value of asset or liability, as the measurement process in this case, depends on unobservable inputs subject to the management subjective decisions (Ronen, 2012). Ronen (2012) outlined the risks associated with the exit values of financial instruments mainly when the optimal conditions (existing liquidity and active markets) are not met once in event of markets illiquidity. Kaya (2013) posits that fair value estimation approach deficient most especially in respect to level three aspect of fair value hierarchy which relied majorly on unobservable inputs that are highly subjective. The criticism of level two and three of fair value evaluation approach is based on its subjectivity in judgment that result to uncertainty and error in fair value evaluation (Bratten, 2013; Ronen, 2008; Bell \& Griffin, 2012; Lilien, 2013). The high level occurrence of errors measurement in fair value of financial statements elements contributed to the collapse of many banks lately, this underscore the relevance and reliability of fair value accounting approach (Bies, 2005; Valencia, Smith \& Ang, 2013).

In extension, Mauro, Guido, and Elisa (2017) states that the variation and complex nature of entities trading financial instruments have increased; therefore the call for independent verification of fair value evaluation has become necessary. However, verification of estimate that is based on unobservable market prices is highly demanding and challenging, the result derived from this unreliable process will definitely be a methods selected by management on the basis of discretions and probability. This infers that, estimates based on these criteria will be hard to verified and establish. This means that, stakeholders (users of financial statements) may suffer great economic loss from any economic decisions on the result of fair value estimation based on such complex and unverifiable method. This has increased the emphasis on the need for understanding on how entities liabilities and assets are estimated and how reliable and relevance the estimation method is when making decision based on it

In contrast to historical cost, FVA relies on several assumptions about the future, many of which may not be verifiable. In financial institutions, there are serious concerns about the verifiability of level 2 and 3 FV assets and liabilities which heavily rely on managerial assumptions; this has been described in literature as "marked-to-myth (Kolev, 2008). Fiechter and Novotny-Farkas (2011), highlights similar concern about the reliability of FVA information, using a global sample of 322 banks that applied IFRS in 2008 and reported that, FVA information is value relevant, but its pricing differs across firm specifics and institutional factors. And also, FVA may result to an increase in volatility of reported earnings and thereby providing a misleading image of firm's underlying performance (Benston, 2008).

In the light of the above arguments, it can be inferred that fair value accounting compromises the reliability of financial reporting and induces artificial volatility. On the other hand, consistent with prior views (Ebling (2001; Poon 2004), fair value accounting provides financial markets with relevant information that embeds expectations of firms' future cash flow performance. Therefore, whether fair value improves the information environment and financial reporting quality is an open question for future research. And also, in a situation of illiquidity, lack of active market, high price volatility and dominant government regulation that characterized the emerging markets environments like Nigeria, couple with difficulties in verification of fair value evaluation methods (level 2 and 3), has created an open door for an empirical investigation on what effects will fair value accounting approach have on the relevance and reliability of entities financial reporting? To verify these claims, 
INTERNATIONAL JOURNAL OF ACADEMIC RESEARCH IN BUSINESS AND SOCIAL SCIENCES

Vol. 9, No. 6, June, 2019, E-ISSN: 2222-6990 @ 2019 HRMARS

we strongly encourage an empirical investigation in this direction in order to establish the effect of fair value accounting on financial statements relevance and reliability most especially in a developing countries.

\section{Financial Instruments Measurement}

Still on fair value contentions issues, is the measurement of financial instruments versus nonfinancial instruments, here, there exist a fundamental inconsistency at fair value and historical cost value. Standard setting bodies identifies that the variation on the treatment of financial statement items (financial and non-financial elements) with different measurement approaches result to inconsistencies and complexities outcomes. Hague (2002) asserts that, there is an economic sense for drawing a line between financial and non-financial items in entities financial reporting. He asserts that, the periodic returns on entities financial instruments are categorized into three components with separate sustainability and certainty. The first two components amortized cost interest and the difference between fair value interest and amortized cost interest-sum to fair value interest. It is pivotal to identify these two components of fair value interest; the reason is that, amortized cost interest is both sustainable and certain, while the variation on fair value interest and amortized cost interest is sustainable but uncertain. This is possible because unexpected variation in interest rates and the resulting unexpected variation in fair values significantly affect fair value interest estimation throughout the lives span of financial instruments. According to Leggett, Wilkins, \& Clark (2015), the resultant effect from this situation is that, an unexpected gain on a financial asset due to a decrease in interest rates in the current period reduces expected fair value interest revenue on the asset life duration. Ryan (2002), this component of the periodic returns to financial instruments is the unexpected change in their fair values during the period and this unexpected change in the fair values of financial instruments are both unsustainable and uncertain. How does these unexpected and uncertainty associated with fair value approach affect the quality of financial report? Here comes again another call for future empirical investigation to affirm or negate prior findings.

\section{Pro-Cyclical Effect of Fair Value Accounting}

In literature, pro-cyclicality is the tendency of financial institutions action to exacerbate in a period of market growth and market downturns. The argument is that, during market growth era, the value of asset on financial statements of financial institutions will be marked up using fair value accounting, and the financial institutions capital base will correspondingly increase. The implication of this scenario is that, financial institutions capital base relative to minimum regulatory capital will thereby increase, given the appearance of the availability of excess capital over the regulatory capital. In consequence, this will motivate financial institutions to increase their assets by undertaking more lending and more risky lending in order to increase profits. The continuation of this act will fuel further market growth, exacerbating the growth cycle. On the other hand, in a situation of a declining economic downturn, the opposite will be the case, that is, entities' assets value will fall as assets are marked down in accordance with mark-to market principles. In such situation, the risk rating of assets will also deteriorate. It is this artificial created market condition resulting from fair value accounting as alleged in literature that described as pro-cyclical effect of fair value in the global financial crisis in 2007 - 2009 (Ryan, 2008). 
Sequel to the development and implementation of accounting standards, companies had freedom in making choices of accounting practices and policies (Prochazka, 2011). During the earlytwentieth century, market value was the common practice; this involved the upward revaluation of long-term assets such as property, plant, equipment and intangible assets. Moreover, prior to1938, financial institutions were mandated to present financial report on loans and other financial assets at current market values (Watanabe, 2007). However, during 2007 to 2009 global economic recession, the market values of entities' assets declined. Following the above scenerio, financial institutions were compelled to mark down their financial assets, this situation made entities to report losses and reduce their capital in order to meet up to the legally required minimum capital adequacy ratio. This behavior negatively affects entities operations which intensified the economic crisis otherwise refer in fair value literature as pro-cyclical. As entities progressed, the market value (fair value valuation method) was later replaced with historical cost evaluation method (Prochazka, 2011; Barley \& Haddad, 2003).

Fair value accounting measure and its reliance on the development of the market condition result to a market that experiences a slump; this is closely followed by an epileptic entities financial condition that in turn makes the market to panic, bringing it nearer to an outbreak of a financial crisis (Catty, 2009). The reason for the possibility of this situation is that, financial institutions are closely related to firms and the business operating life cycle in general. Therefore, if fair values shows a decline, losses will also be reflect on the capital of financial institutions. Following the recent global financial crisis of 2007 and 2009, the arguments on the contribution of fair value accounting to the crisis have been on the increase. The inherent potentiality of fair value accounting estimate to exaggerate market situation is high, and the resulting effect is the artificial creation of market situation capable of making investors to panic, and therefore, increasing the pro-cyclicality of the financial system arising from exaggeration of financial or economic fluctuations. (Coopers, 2015).

To the best of our knowledge, this conceptual believe has not been empirically investigated, especially in the emerging market economies. At present, it stands as an unresolved issue in fair value literature that calls for a future empirical verification, to establish if truly, fair value accounting has the inherent potential of causing a pro-cyclical situation in an economy. Also, it is asserted that, valuation based on this accounting measurement approach, enhances a downward spiral in prices and investor confidence. In a situation of such, entities write down when prices decrease, entities could be compelled to dispose off assets in order to meet up a level of compliance with government's stated rules and regulations of capital requirements. Therefore, the end result that accompanies this situation is a steady and continuing downward pressure on assets pricing (PricewaterhouseCoopers, 2015). The contentions on fair value accounting in the context of pro-cyclicality is still an ongoing issue in fair value literature, this arises from the suspicious creation of global financial turmoil in 2008. One of the notable study before the financial global crisis that proposed the likelihood of fair value accounting measure resulting to a pro-cyclical situation is that of Barth (2004). In his findings, he discovered that a mixed-measurement accounting system; that is, a situation where fair value accounting treatment is selectively apply to assets and liabilities of an entity, could fuel a negative growth which could result to a pro-cyclical effect and increase of high level of volatility in earnings in contrast to the use historical cost accounting approach. 
However, in fair value accounting literature, two situations play out, the first is the sequence of cause and effect that exists in economics, and relating this to issue of fair value is pivotal to financial reporting quality; the second side of the cause and effect of fair value is that, fair value accounting is a proactive evaluation approach that gives early warning signs for an incoming financial crisis and therefore may compel corporate entities to take rightful and proactive decision earlier. What this means is that, the application of fair value accounting could actually ameliorate the level of severity effect of a crisis on firms financial statements (Laux \& Leuz, 2009).

\section{Fair Value Measurement versus Earnings Quality}

The conceptual evaluation of fair value accounting literature revealed that, the shift from the traditional historical cost-based accounting model to a fair value (market value) based accounting model has significant consequences on earnings. Every business entity is judged by its earnings as one of the most important parameter to measure the financial performance of the organization. The quality of earnings is an important benchmark to determine the ability to earn consistently in the future and to maintain quality, sustainability and growth in performance. It is important to state that, the judgment of any business corporate entity is on the assessment of its performance in relation to earnings (Mauro et al., 2017). Earnings of business entities are cardinal indicators for measuring the corporate financial performance of business entities. One of the determinants of the future ability of an entity to maintain a consistent quality and growth in performance is the earnings quality (Gadhia, 2015). The transition of accounting measurement approach from historical cost method to fair value accounting method has great significance change on the properties of financial reporting. Although, up till date, no consensus has been empirically achieved as relate to the effect of fair value accounting approach on earnings quality of corporate entities. Probing the relationship between fair value accounting and earnings and effectiveness of fair value measurement approach, it is important to empirically investigate how FVA contribute to the achievement of the overall objective of financial reporting quality and decision relevance of information to various stakeholders (International Accounting Standard Board, 2010).

The literal evaluation of the use of fair value accounting appeared well in an uninterrupted market environment, the relevance, integrity, and reliability of fair value measure reduces when markets mechanisms do not run. In such condition, fair value is estimated using unscientific methods which permits earnings manipulation and could result to a reduction of earnings quality. Estimation based on fair value accounting creates opportunity for managerial discretion and intended judgment capable of reducing the financial reporting quality of corporate entities (ljeoma, 2014; Ryan, 2008; Hitz, 2007; Nissim, 2003). Moreso, fair value measurement approach does not reflect the actual cash flows and underlying economic situation, as the valuation contains noise attributed to market sensitivity other than economic fundamentals. A critical view on literature revealed that, in an illiquid market environments, the processes of market prices to evaluate the assets and liabilities of entities may not be relevant since the circumstance prices does not always correlates to present discounted value of expected cash flows (Sodan, 2015). Also, prior studies evidenced that the fair value measurement approach is less significant when based on unreliable observable inputs (Song, Thomas, \& Yi, 2010; Simko, 1999; Nelson, 1996). In addition, a critical look through on fair value literature revealed that the value relevance of fair value accounting is not same across time; during the era of 
economic turmoil, fair value decreases due to uncertainty, information risk and illiquidity (Allen \& Carletti, 2008; Hung, 2000). Other studies that also flawed and demonstrate that fair value estimations are less significant when they are based on unreliable observable inputs are the studies of (Nelson, 1996; Simko, 1999; Song, Thomas, \& Yi, 2010).

However, contrary to the above assertions, some prior studies advanced some reasons why fair value accounting approach could improve accounting quality (ljeoma, 2014; Liu et al., 2011; Barth \& Clinch, 2008). Most prior studies on fair value accounting examined the reliability of fair value accounting information for investors in capital markets, and the supporters of fair value accounting assert that market prices are the most and reliable significant appropriate measures of assets and liabilities of any given business entity (Ryan 2008; Barth \& Clinch, 1998; Barth, 1994). There exist empirical studies in fair value accounting literature that assert that, the application of fair value accounting has really improved the level of formativeness of the accounts, and that, fair value accounting offered reliable and relevant information regarding the volume, uncertainty and timing of future cash flows (Barth, 2008; Landsman, 2007; Hitz, 2007). One of the important statements in value relevance studies is that, fair value accounting has the inherent ability to predict an entity's cash flows in future realizations. That is, fair value valuation shows the current value of predictable future cash generation.

Therefore, the relevance of fair value accounting can be drawn from its productive aptitude in assessing the expected entities' earnings and cash flows. More also, fair value valuation is a consistent measure of assets' values. (Barth, 2000). Specifically, the financial reporting system of financial institutions are particularly exposed to fair value accounting, a number of studies investigated the predictive ability of fair value accounting in the banking sector performance. Particularly, as the statements of financial position of financial institutions are predominantly financial instruments which are mostly recognized at fair value. For instance, the performance literature on banking industry, Hill (2009) assert that amplified exposure to fair value accounting has an inherent ability to improve the financial reporting capacity of entities' earnings to predict future cash flows. However, other fair value prior studies equally cautioned the application of Hill (2009) empirical findings concerning the predictive aptitude of fair value; that, his findings cannot be generalized due to the variations in reported fair values in other comprehensive income of an entity could be temporary within a high volatile market situation, therefore, this limitation make fair value accounting to lack the ability to amplify earnings capacity to expect future operating performance (Jatinder, 2017; Smith, 2011; Dhaliwal, Subramanyam, \& Trezevant, 1999).

Still on fair value prediction, other prior empirical studies investigate and linked high ranks of earnings volatility with fair value accounting (Sun, Liu, \& Cao, 2011; Magnan, 2009; Sole, Novoa, \& Scarlata, 2009; Plantin, Sapra, \& Shin, 2008; Hodder, Hopkins \& Wahlen, 2006; Barth, 2004; Bernard, Merton, \& Palepu, 1995; Barth, 1995). Barth (2004) pointed out that financial statement volatility itself is not a sign of defective financial reporting, it is the evaluation based on the result of fair value accounting estimation that is defective, since the future cash flows of entities are uncertain. Estimation error on volatility tends to be lower if fair value is estimated using the prices that are available in active markets, otherwise called "mark to market". And on the other hand, valuation error tends to be higher in situations when prices are not available in active markets, and when fair value is based on subjective valuation model (Mauro, Guido \& Elisa, 2017). Kirschenheiter and 
Melumad (2004), opined that, high quality earnings are more relevant, as it better signify the future performance of an entity. Also, in the findings of Revsine, Collins, and Johson (1999); DeFond (2010) argued that earnings are of higher quality only if they are maintainable. Again, the research question that flow from these conflicting assertions is; how would a fair value accounting approach influence entities' earning quality? This is a remarkable issue in FVA that demand future empirical clarity.

\section{Conclusion and Recommendations}

The methods of accounting estimate that produce reliable financial reporting for decision usefulness to various stakeholders have been of great concern to accounting standard-setters around the world. The different conceptions of what is for an accounting estimate to be reliable underlie the fair value debate as it has taken shape in the last decade. The quest for reliable financial reporting is a major reason for the transition from historical cost estimate to fair value estimation approach. The study revealed that prior before the inception and adoption of International Financial Reporting Standards (IFRS); fair value accounting has been lightly in practice. This study has conceptually revealed that; level 2 and 3 fair value valuation, price volatility, market illiquidity, and inactive market, affect the value relevance and reliability of financial report prepared under fair value accounting approach. However, despite the present cloudiness and shortcomings surrounding fair value estimation approach now, the approach looked promising. Hence, we recommend the followings:

1. We encourage local empirical investigation to address issues such as; the effect of FVA on earnings quality, the truism of the cyclical effect of FVA, and the relevance and reliability of FVA in an emerging country like Nigeria which is characterized with illiquidity, market frictions, high level government regulation, and high level price volatility.

2. Standard setters should strive to limit uncertainty in financial markets by setting the necessary rules to value financial assets and liabilities in clear guidelines, especially under level 3 of fair value hierarchy.

3. To harness full benefits of FVA, there is need to improve the developing countries' business environment through free trade agreement with developed countries in order to create active markets.

4. There is need for a research programs for professional accounting bodies and practitioners' forums so as to identify, develop and formulate a conceptually superior accounting framework that cuts through the ambiguities presently associated with FVA.

5. There is need to exercise caution in the application of fair value accounting most especially in a time of economic crisis in order to avert the cyclical effect of it.

\section{References}

Allen, F., \& Carletti, E. (2008). Mark-to-market accounting and liquidity pricing. Account and economics review, 45(2), 358-378.

Alves, F. E., Botinha, R., Silva, P. R., \& Lemes, S. (2015). Comparability of Accounting Choices in Future Valuation of Investment Properties: An Analysis of Brazilian and Portuguese Listed Companies. Revista Contabilidade \& Finanças, 26(68), 154-166.

Barth, M. E. (2008). Global financial reporting; implications for US academics. Accounting review, 83(5), 1159-1179. 
INTERNATIONAL JOURNAL OF ACADEMIC RESEARCH IN BUSINESS AND SOCIAL SCIENCES

Vol. 9, No. 6, June, 2019, E-ISSN: 2222-6990 @ 2019 HRMARS

Barth, M. E. (2007). Standard setting measurement issues and the relevance of research. Accounting and Business Research, Special Issue, 7(1), doi.org/10.1080/00014788.2007.9779.

Barth, M. E. (1991). Relative measurement errors among alternative pension asset and liability measures. The Accounting Review, 66, 433-463.

Barth, M. E. (2004). Fair Values and Financial Statement Volatility", in The Market Discipline Across Countries and Industries, Edited by Claudio Borio, William Curt.

Barth, M. E., Landsman, W. R., \& Wahlen, J. (1995). Fair value accounting: effects on banks' earnings volatility, regulatory capital, and value of contractual cash flows. Journal of Banking and Finance, 6(7), 577-605.

Barton, J., Hansen, T. B., \& Pownall, G. (2010). Which performance measures do investors around the world value the most-and why? Accounting Review, 85(3), 753-789.

Bartov, E., Goldberg, S. R., \& Kim, M .(2005). Comparative value relevance among Germany, U.S. and international accounting standards. A German Stock Market Perspective, 20(2), 95-119.

Bernard, V. L., Merton, R. C., \& Palepu, K. G. (1995). Mark-to-market accounting for banks and thrifts: lessons from the Danish experience. Journal of Account Res. 33(1), 1-32.

Benston, G. J. (2008). The shortcomings of fair value accounting according to SFAS 157. Journal of Accounting and Policy, 27(2), 101-114.

Bies, S. S. (2005). Fair value accounting. Federal Reserve Bulletin, 91, 26-30.

Bratten, B., Causholli, M., \& Khan, U. (2012). Fair value accounting and the predictive ability of earnings: evidence from the banking industry, Available at SSRN: http://ssrn.com/abstract=2165996.

Catty, J. (2009). Guide to fair value under IFRS. John Wiley \& Sons, ISBN 978-0-470-47708-3, New Jersey, USA.

Casualty Actuarial Society (2000). Casualty actuarial society research. http://www.casact.org.

Dhaliwal, D., Subramanyam, K. R., \& Trezevant, R .(1999). Is comprehensive income superior to net income as a measure of firm performance? Journal of Account and Economics, 26(1), 43-97.

Chambers, A. (2008). How do you mark to market? Euro money, 1-3

DeFond, M. L. (2010). Eq research: advances, challenges and future research. Journal of Account and Econ, 50(2), 402-409.

Ebling, P. (2001). Fair value accounting: Breaking a butterfly upon a wheel? Balance Sheet, 9, 22-27.

Eckstein, C. (2004). The measurement and recognition of intangible assets: then and now. Accounting Forum, 28(2), 139-158. doi.org/10.1016/j.accfor.2004.02.001

Financial Accounting Standards Board. (2009). Accounting Standards Code 820. Fair Value Measurements. USA.

Fiechter, P., \& Novoting-Frarkas, Z. (2011). Pricing of fair values during the financial crisis, international evidence. Working paper, University of Zurich and Goethe-University of Frankfurt.

Hague, I. (2002). Fair value for financial instruments: Where to next? Balance Sheet, 10, 8-12.

Hill, M. S. (2009). Fair value earnings as a predictor of future cash flows, University of Alabama Working Paper.

Hitz, J. M. (2007). The decision usefulness of fair value accounting, a theoretical perspective. European Accounting Review, 16(29), 323-362. 
INTERNATIONAL JOURNAL OF ACADEMIC RESEARCH IN BUSINESS AND SOCIAL SCIENCES

Vol. 9, No. 6, June, 2019, E-ISSN: 2222-6990 @ 2019 HRMARS

Hodder, L. D., Hopkins, P. E., \& Wahlen, J. M. (2006). Risk-relevance of fair value income measures for commercial banks. Accounting Review, 81(2), 337-375.

Hung, M. (2000). Accounting standards and value relevance of financial statements and international analysis. Journal of Accounting and Economics, 30(3), 401- 420.

ljeoma, N. B. (2014). The contribution of fair value accounting on corporate financial reporting in Nigeria. American Journal of Business, Economics and Management, 2(1), 1-8.

Ilaboya, O. J. (2008). Advance Financial Accounting, $2^{\text {nd }}$ Edition. Mindex Press Ltd. Benin City Nigeria. International Accounting Standards Board. (2012). International Financial Reporting Standard 13, Fair Value Measurements. USA

Jones, D. A., \& Smith, K. J. (2011). Comparing the value relevance, predictive value, and persistence of other comprehensive income and special items. Account Review, 86(6), 2047-2073.

Kirschenheiter, M., Melumad, N (2004). Earnings quality and smoothing, Working Paper, Columbia Business School.

Kolev, K. (2008). Do investors perceive marking to model as marking-as-myth? Early evidence from FAS 157 disclosure. Working paper, Stern School of Business, New York University.

Krumwiede, T. (2008). Why historical cost accounting makes sense, Strategic Finance, August, 33-39. Landsman, W. R. (2007). Is fair value accounting information relevant and reliable? Evidence from capital markets. Accounting and Business Research, 37(1), 19-30.

Laux, C., Leuz, C. (2009). The crisis of fair-value accounting: marking sense of the recent debate. Accounting Organization Society, 34(6/7), 826834.

Laux, C., \& Leuz, C. (2010). Did fair-value accounting contribute to the financial crisis? Journal of Economics Perspective, 24(1), 93-118.

Leggett, D., Wilkins, A., \& Clark, S. (2015). The frequency, magnitude, and measurement subjectivity associated with liabilities reported at fair value. Academy of Accounting \& Financial Studies Journal, 19(1), 160-170.

Liu, C., Yao, L. J., Hu, N., \& Liu, L. (2011). The impact of IFRS on accounting quality in a regulated market. Accounting, Audit Finance, 26(4), 659-676.

Lilien, S., Sarath, B., \& Schrader, R. (2013). Normal Turbulence or Perfect Storm? Disparity in Fair Value Estimates. Journal of Accounting, Auditing \& Finance, 28(2), 192-211. http://dx.doi.org/10.1177/0148558X13479693.

Magnan, M. L. (2009). Fair value accounting and the financial crisis: messenger or contributor? Accounting Perspectives, 8(3), 189-213.

Mauro, P., Guido, P., \& Elisa, M. (2017). Fair value accounting and earnings quality in banking sector: Evidence from Europe. African Journal of Business Management, 11(20), 597-607.

Nelson, K. K. (1996). Fair value accounting for commercial banks: An empirical analysis. Accounting Review, 71(2), 161-182.

Nissin, D., \& Penman, S. (2008). Principles for the application of fair value accounting. White Paper No. 2, Columbia Business School.

Nissim, D. (2003). Reliability of banks' fair value disclosure for loans. Quantitative Finance, Accounting Review, 20(4), 355-384.

Okafor, C., \& Ogiedu, K. O. (2012). Perceptions of fair value accounting: evidence from Nigeria, JORIND, 10(3), 417-432. 
INTERNATIONAL JOURNAL OF ACADEMIC RESEARCH IN BUSINESS AND SOCIAL SCIENCES

Vol. 9, No. 6, June, 2019, E-ISSN: 2222-6990 (C) 2019 HRMARS

Plantin, G. H., Sapra, H., \& Shin, H. S. (2008). Marking-to-Market: panaceo or pandora's box? Accounting Review, 46(2), 435-460.

Poon, W. W. (2004). Using fair value accounting for financial instruments. American Business Review, 2(2), 39-44.

Power, M. (2010). Fair value accounting, financial economics and the transformation of reliability, Account Business. Reserve. 40(3), 197-210.

Prochazka, D. (2011). The role of fair value measurement in the recent financial crunch. Prague Economic Papers, 1, 71-88.

PWC (2015). Fair value measurement, 20101

Revsine, L., Collins, D., \& Johson, B. (1999). Financial reporting and analysis, Prentice Hall, Upper Saddle River, New Jersey.

Ryan, S. G. (2008). Accounting in and for the subprime crisis. Accounting Review, 83(6), 1605-1638.

Simko, P. J. (1999). Financial instrument fair values and nonfinancial firms. Accounting and Finance Journal, 14(3), 247-274.

Sodan, S. (2015). The impact of fair value accounting on earnings quality in eastern European countries. Economics Finance Journal, 32(5), 1769-1786.

Sole, J. A., Novoa, A., \& Scarlata, J. (2009). Procyclicality and fair value accounting, IMF Working Paper No. 9/39, International MonetaryFund (IMF).

Song, C. J., Thomas, W. B., \& Yi, H. (2010). Value relevance of fair value hierarchy information and the impact of corporate governance mechanisms. Account. Review, 85(4), 1375-1410.

Sun, P., Liu, X., \& Cao, Y. (2011). Research on the income volatility of listed banks in China based on the fair value measurement. International Business Review, 4(3), 228-233.

Watanabe, I. (2007). The evolution of income accounting in eighteenth and nineteenth century Britain Osaka keidai Ronshi. 